\title{
Field and petrographic characterization of some building, ornamental and industrial raw materials of the Tertiary sedimentary succession of Haddat Ash Sham Area, West Central Arabian shield, Saudi Arabia
}

\author{
Abdullah Rasheed Sonbul \\ Faculty of Earth Sciences, King Abdulaziz University, P. O. BOX 80206, Jeddah, 21589, Saudi Arabia.
}

Accepted 26 June 2013

\begin{abstract}
The present study has dealt with the field and microscopic description of different building, industrial and ornamental stones of the Tertiary sedimentary succession of Haddat Ash Sham area, Saudi Arabia. The described building and ornamental stones includes: quartz pebble conglomerates, sandstones, limestones, dolostones and clays. The stratigraphic setting, mega and microscopic description of the different types of building and ornamental stones revealed the predominance of the quartz-pebble conglomerates in the lower and upper members of the Tertiary succession of the study area while the clays and carbonates are present in the middle member of this succession. The quartz pebble conglomerates represents the most important building material which is mostly suitable for concrete industry while the sandstones are present as very thick hard ferruginous cliffs suitable for dimensional blocks for facing and decoration. The carbonates are represented by relatively thin horizons of limestone and dolostones which is easily extracted and used for concrete industry. The clay deposits are present in many levels within the sedimentary succession of Haddat Ash Sham area and represent the same extensions of the clay quarries used for brick industry in Ash Shamiyah area west of Haddat Ash Sham area. The studied building and ornamental stones need further engineering tests and measurements for the accurate evaluations from the engineering points of views. The reserves of the clay deposits must be evaluated from the economic points of views for cement and ceramic industries.
\end{abstract}

Key words: Saudi Arabia, Haddat Ash Sham area, building and ornamental stones, quartz pebble conglomerates and concrete materials.

\section{INTRODUCTION}

Geologic setting

Haddat Ash Sham area lies about $70 \mathrm{~km} \mathrm{~N}$ to $\mathrm{NE}$ of Jeddah city (Figure 1a, b) between latitude $21^{\circ} 50^{\prime} 00^{\prime \prime}$ and $21^{\circ} 50^{\prime} 19^{\prime \prime} \mathrm{N}$ and longitude $39^{\circ} 43^{\prime} 38^{\prime \prime}$ and $39^{\circ} 44^{\prime}$ $00^{\prime \prime} \mathrm{E}$. This area comprises crystalline Precambrian
Arabian Shield rocks overlain by the Tertiary sedimentary succession, and the Quaternary-Recent alluvial deposits. The Arabian Shield rocks of the study area have been studied by Al-Shanti (1966) and Moore and Ar-Rehaili (1989). According to the Arabian Shield map (Johnson, 2006) the Precambrian rock units (Figure 2) are 

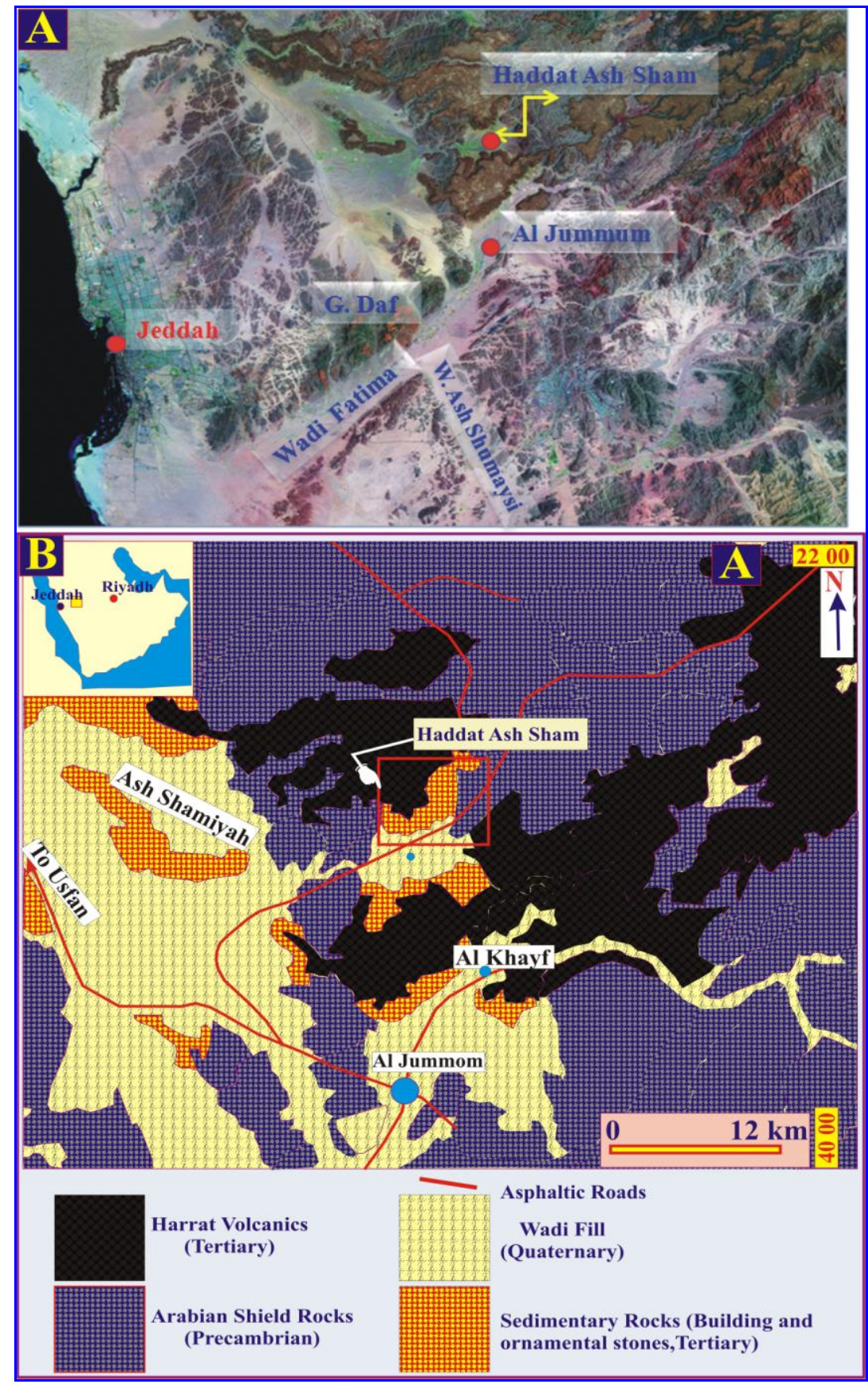

Figure 1. $A=$ Satellite Image of Jeddah-Makkah district showing the mapped area of Figure B; B= Generalized geologic map of Haddat Ash Sham area (Modified after Johnson, 2006).

represented by:

(1) unassigned diorite and unassigned granodiorite and tonalite,

(2) The Cryogenian layered rocks which are represented by the Samran (sa), Zibarah (Zf) and Fatimah groups $(\mathrm{Ff})$,
(3) The Cryogenian intrusive rocks that are represented by:

(A) the Samd tonalite (Mt), the Hashash granite $(\mathrm{Ig})$, the Kamil suite $(\mathrm{Km})$ and finally the Ramayda granite (Ry) and,

(4) The Edicarian layered rocks are represented by the Shyma Nasir group (Sn). 


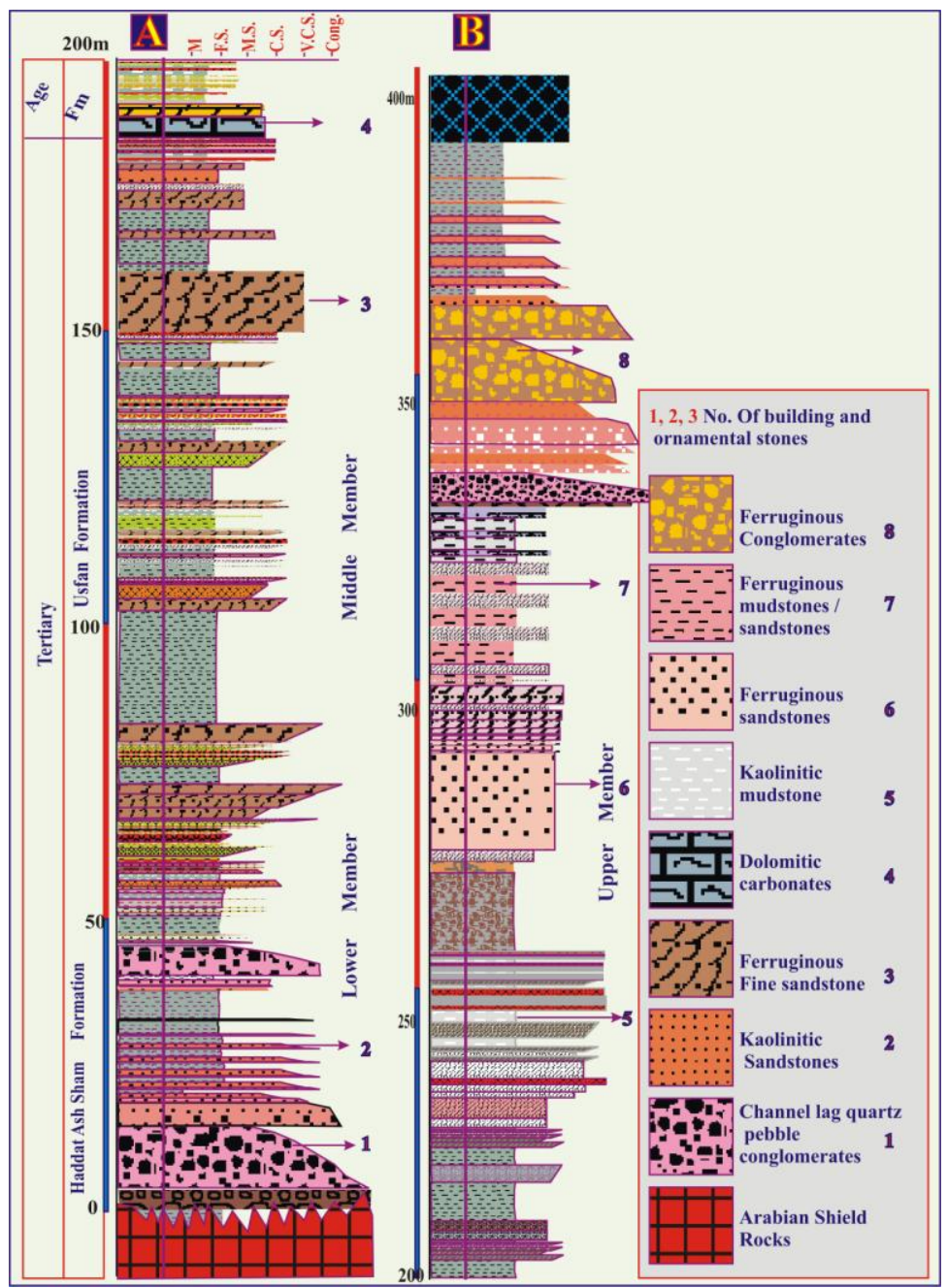

Figure 2. Stratigraphic section of the Tertiary sedimentary succession of Haddat Ash Sham area (modified after Taj (2011)) showing the stratigraphic setting of the studied building and ornamental stones (No 18).

The Cretaceous-Tertiary sedimentary rocks are assigned Shumaysi and Usfan formations (Brown et al., 1963; Karpoff 1957a, b). The Shumaysi Formation was further subdivided into the Haddat Ash Sham, Shumaysi, Khulays, and Buraykah formations (Spincer and Vincent, 1984). The Tertiary sequence of the study area is recently described by Taj (2011) as a thick siliciclastic succession deposited during interplay between alluvial fans, fluvial-shallow marine and lacustrine depositional environments. They subdivided this succession into three main members (Figure 2; Figure 3a, b), these are: lower fluvio-lacustrine clastic member, middle shallow marine oolitic ironstones-carbonate member and an upper tidal flat fluvio-lacustrine clastic member. The lower fluviolacustrine clastic member is composed mainly from two main channels of characteristic three fining-upward cycles. Each of these cycles began by massive disorganized conglomerates that grades upwards into trough and tabular cross-bedded kaolinitic and ferruginous conglomerates and pebbly sandstones then into tabular cross-bedded to cross-laminated fine-grained sandstone, siltstone and ferruginous mudstones. The middle shallow marine oolitic ironstone-carbonate member attains up to $150 \mathrm{~m}$ thick and consists of characteristic shallowing and coarsening-upward cycles. The upper tidal flat fluvio-lacustrine clastic member forms the thick mudstone, sandstone and conglomerates stacked in fining and coarsening-upward cycles. This member represents the upper parts of the Tertiary succession in the study area just overlying the middle ironstone-bearing member.

The present study aims to shed light on the field and microscopic characterization of the building, ornamental and industrial minerals and rocks of Haddat Ash Sham 
area. These aims are achieved throughout systematic scientific methods and procedures.

\section{METHODS OF STUDY}

The study is based on systematic scientific methods which include the following:

(1) field measurements and description of the stratigraphic setting of the different building, ornamental and industrial raw materials,

(2) drawing the stratigraphic section of the studied section,

(3) mega-scopic description of the selected samples,

(4) description of the prepared thin sections of the studied building, ornamental and industrial raw materials,

(5) preparation of the selected samples for the chemical analyses throughout the following procedure: the samples were firstly dried to $105^{\circ}$ and then crushed to $75 \%$ passing of 10 mesh and then splitting nominal weight of $50 \mathrm{~g}$, which are pulverized using tungsten bowls and packed for analyses. The analyses were carried out by XRF Shimadzu 1700 , and

(6) formulating the resulted data and finalization of the manuscript in its present form.

\section{BUILDING, ORNAMENTAL AND INDUSTRIAL RAW MATERIALS}

The vertical distribution of the studied building, ornamental and industrial raw materials from base (No. 1 to 9) is clarified on the complete stratigraphic section of the study area Taj (2011). The description of the raw materials is given below:

\section{(1) Channel lag quartz pebble conglomerates (No. 1)}

This conglomerate type is present along the contact between the Arabian shield rocks and the overlying siliciclastic succession (Figure $3 c$ ). It is present as massive red rosy colored pebbles cemented by kaolinitic and ferruginous conglomerates (Figure $3 \mathrm{c}, \mathrm{d}$ ). When these massive disorganized conglomerates become weathered, they give friable quartz pebbles suitable for concrete industry. This massive conglomerate bed is overlain directly by bedded conglomerates and pebbly sandstone (Figure $3 \mathrm{e}, \mathrm{f}$ ). This unit attains up to $8 \mathrm{~m}$ thick and shows lateral and vertical faces variations.

The microscopic description of the pebbly sandstone beds intercalated with the red quartz pebble conglomerates of unit No. 1 revealed that it consists of angular to subrounded, moderately sorted quartz grains embedded in amorphous kaolinitic clay matrix (Figure $3 \mathrm{~g}$ ). The progressive hematitization of this kaolinitic clay matrix led to the formation of black cement of hematite crystallites and patches (PI. $1 \mathrm{H})$. Ultimate stages of hematitization led to the coalescence of the small hematite crystallites and formation of larger black hematite domains enclosing small quartz grains (Figure $4 a, b, c)$. The quartz grains becomes highly corroded and embayed by the enclosing hematite cement (Figure 4d). This resulted in the formation of smaller quartz island floating in the hematite cement (Figure 4d). This hematitic coarse-grained sandstone- pebbly sandstone is present alternated with the white and bluish white kaolinitic coarse sandstone.

This type can be classified according to the rock type classification of natural aggregate according to BS812: Part 1 (1975, Trade group classification, Table 1) as Flint and Gritstone groups. After the destruction and quarrying of the these quartz-pebbles bearing beds, the resulted ill sorted quartz pebbles can be extracted as a raw material for cement industry and concrete. As the studied conglomerates are composed mainly of red and white color quartz lag pebbles and not containing weak pieces as chert, shale, and siltstone, they are good for aggregates in concrete, and free of unsound an weathered piece that causes pop-outs at the concrete surface after freeze-thaw cycles.

\section{(2) White kaolinitic and tuffaceous sandstone (No. 2)}

The sandstones represent the most important raw material in Haddat Ash Sham area. It is present just overlying the above mentioned red quartz pebble conglomerates (No. 1). It attains up to $100 \mathrm{~m}$ thick and it is of bluish white and white colors (Figure 4e). This unit consists of interbedded white and grey tuffaceous and kaolinitic sandstone and mudstones (Figure 4f). Some pebbly sandstone interbeds are present in the upper part of this unit. This unit is terminated by yellow grey calcareous sandstones (Figure 4f). This unit is also changed laterally into the above described unit No.1. Both units 1 and 2 are of high economic importance.

The microscopic description of the White kaolinitic and tuffaceous sandstone (No. 2) led to the recognition of ill sorted, medium size quartz grains embedded in slightly crystallized to amorphous isotropic kaolinitic/ tuffaceous clay matrix (Figure 5a). Silicified poorly sorted sandstone variety also observed (Figure 5b). The quartz grains are cemented together by silica over growth and they are sutured within each other (Figure 5b). Quartz grains are mostly monocrystalline and of wavy extinction. Polycrystalline quartz grains were also observed (Figure $5 a, c)$. In these polycrystalline grains, the grains are of sutured contact and they are either embedded within amorphous kaolinitic clays matrix or cemented by microcrystalline quartz (Figure $5 \mathrm{~d}$ ). In some domains, the quartz grains, become cemented by gypsum and anhydrites lath-like aggregates (Figure $5 \mathrm{e}, \mathrm{f}$ ). The quartz grains become highly corroded and embayed by the enclosing gypsum cement (Figure 6a). In some domains, the quartz grains become embedded within black (isotropic) material mostly amorphous kaolinitic clay matrix or tuffaceous glassy material (Figure 6b).

This type can be classified according to the rock type 

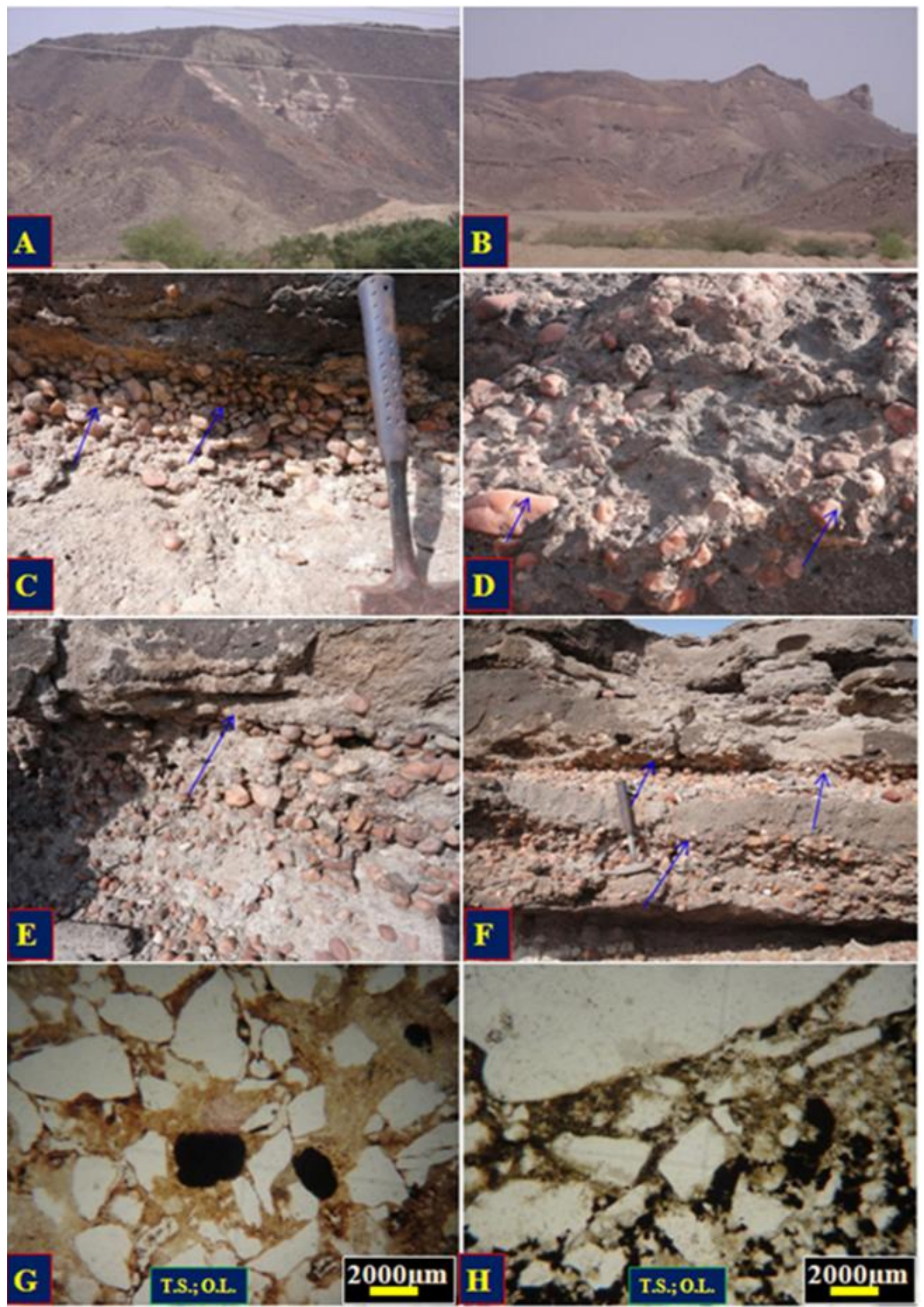

Figure 3. (A, B): General views of the complete sedimentary succession of Haddat Ash Sham area; $(C, D)$ : Massive quartz pebble conglomerate (arrows) along the contact between the Tertiary sedimentary succession and the underlying Arabian Shield rocks; (E, F): Bedded conglomerates and pebbly sandstone (arrows) just overlying the massive quartz-pebble conglomerates; $(\mathrm{G}, \mathrm{H})$ : Angular to subrounded, moderately sorted quartz grains (white) embedded in amorphous kaolinitic clay matrix contains black cement of hematite crystallites and patches. O.L. = ordinary Light; C.N.= Crossed Nicols. 

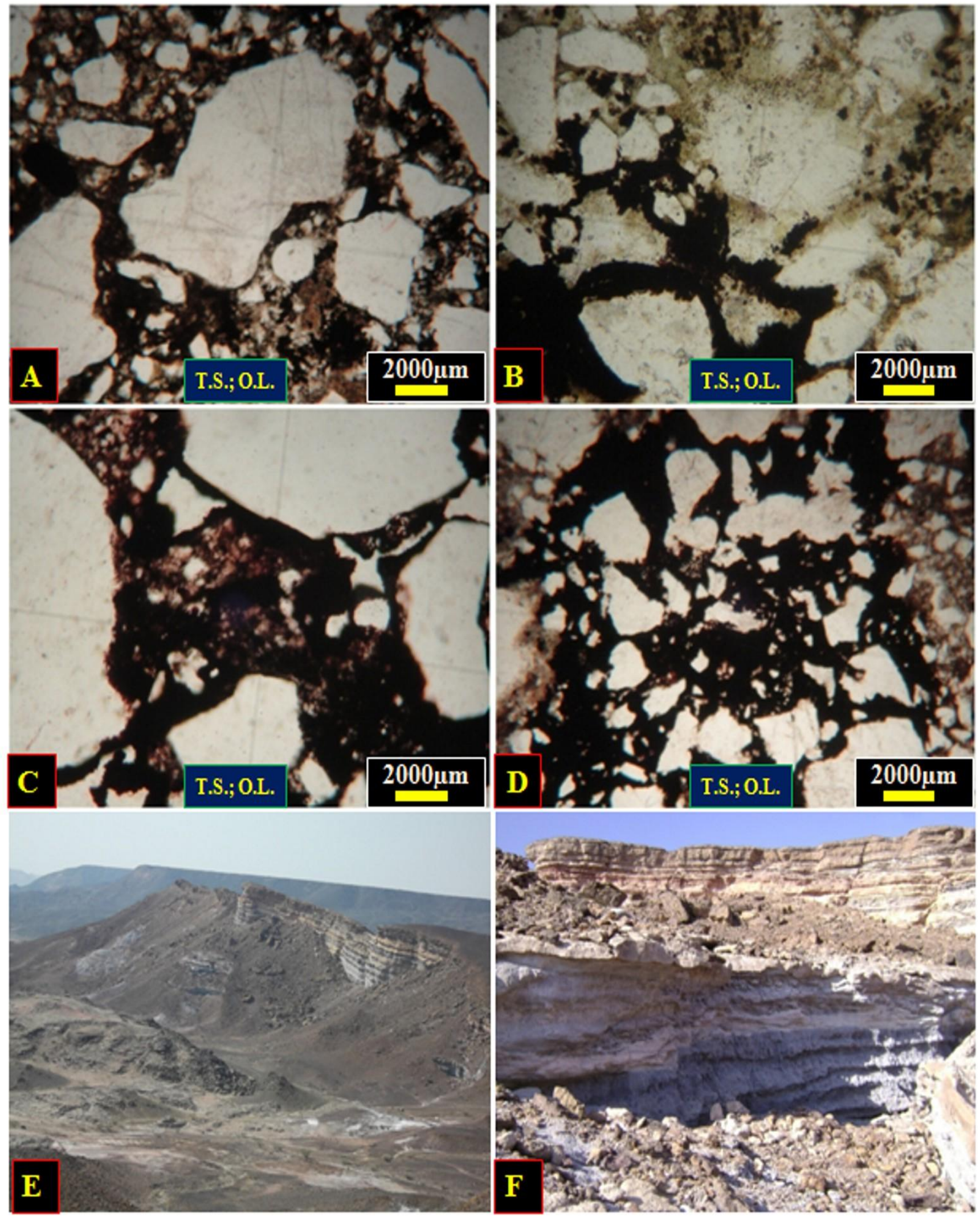

Figure 4. (A, B, C, D): Progressive stages of hematitization and coalescence of the small crystallites (black) and formation of larger black hematite domains and quartz grains (white) becomes highly corroded and embayed by the enclosing hematite cement; ( $E$, $F$ ): Interbedded white and grey tuffaceous and kaolinitic sandstone and mudstones (No. 2). 
Table 1. Rock type classification of natural aggregates according to BS 812 (Part 1, 1975, Trade group classification).

\begin{tabular}{ll}
\hline Classification & \multicolumn{1}{c}{ Contents } \\
\hline Basalt group & Basalt, andesite, dolerite, lamprophyre, spilite, diabase. \\
Gabbro group & Gabbro, diorite ,basic gneiss, norite, hornblend rock, peridotite, serpentinite, picite. \\
Granite group & Granite, pegmatite, granodiorite, syenite, gneiss, quartz diorite. \\
Porphyry group & Prohyry, aplite, rhyolite, felsites, dacite, granophyres, microgranite, trachyte. \\
Hornfels group & Contact rocks of all kinds except marble. \\
Limestone group & Limestone, dolomite and marble. \\
Flint group & Flint and chert. \\
Gritstone group & Arkose, greywacke, conglomerate, grit, sandstone, tuff. \\
Quartzite group & Quartzite sandstone, quartzitic ganister. \\
Schist group & Schist, phyllite. Slate and all sheared rocks. \\
Artificial group & Crushed bricks, slags, synthetic aggregates \\
\hline
\end{tabular}

classification of natural aggregate according to BS812: Part 1 (1975, Trade group classification, Table 1) as Gritstone groups. The fine-grained and the well sorted nature of this sandstone revealed it suitability for building purposes. This sandstone type is also suitable for the glass industry because it is composed mainly of quartz grains with interstitial siliceous cement.

\section{(3) Thick brown ferruginous sandstone (No. 3)}

This sandstone is present within the middle shallow marine ironstone phosphatic carbonates member (Figure 2, Column A, Figure 6c). The sandstone is hard and highly cemented and it forms a thick cliff-forming horizon (Figure 6d). It is composed of fine-to medium-grained, angular to subrounded, moderately to well sort quartz grains (Figure 6e, f). There are two main varieties of this sandstone that is, ferruginous sandstone (Figure 6e) and silicified sandstone (Figure 6f). The ferruginous sandstone is cemented by black hematite cement (Figure $6 e)$. The quartz grains are highly corroded and embayed by the enclosing black hematite cement and hematite domains empty from quartz grains were formed (Figure $6 e, f)$. The other type is silicified sandstone which is composed of moderately to well sort medium-grained quartz grains (Figure 7a). In this type, the quartz grains are cemented by silica overgrowths (Figure $7 b$ ). Some hematite dots are present with the silica over ground (Figure 7a, b).

This type can be classified according to the rock type classification of natural aggregate according to BS812: Part 1 (1975, Trade group classification, Table 1) as Gritstone and Quartzite groups. This silicified sandstone forms thick, non fractured and highly cemented cliffforming blocks of large dimension which suggest the suitability for building and ornamental purposes (Figure 7d). The geochemical analyses of these ferruginous sandstone beds (Table 2) revealed the high $\mathrm{SiO}_{2}$ content (up to 72.21). The $\mathrm{Fe}_{2} \mathrm{O}_{3}$ content of these ferruginous sandstones is about $10.93 \%$ (Table 2). These sandstones contains up to $9.45 \% \mathrm{Al}_{2} \mathrm{O}_{3}$. They are of relatively low Cao, $\mathrm{P}_{2} \mathrm{O}_{5}, \mathrm{MnO}, \mathrm{MgO}, \mathrm{K}_{2} \mathrm{O}$ (Table 2).

\section{(4) Dolomitic carbonates (No. 4)}

This carbonate horizon is present in the middle part of the middle member (Top of Column A, Figure 2). It is present as laterally persistent yellow color horizon within the brownish ferruginous mudstone- sandstone succession (Figure 7c). It attains up to $5 \mathrm{~m}$ thick, and consists of three characteristic horizons, a very thin lower yellow dolomitic mudstone unit, middle thick grayish white fossiliferous limestone unit and an upper thin yellow dolostone unit (Figure 7d). The field and microscopic description of the lower yellow dolostone unit revealed its composition from fine crystalline interlocked dolomite rhombs (Figure 7e). The description of the middle limestone bed revealed the presence of large gastropod shells within finer bioclastic pack and grainstone ground mass (Figure 7f, g). The bioclastic packstone/ grainstone microfacies consist mainly of clacitized (sparitized) shell fragments and micro-fauna embedded in highly recrystallized micrite (microspare, Figure $7 \mathrm{e}, \mathrm{f}$ ). The upper yellow dolostone horizon is composed mainly from interlocked zoned dolomite rhombs (Figure $7 \mathrm{~g}$ ). Most of these rhombs are calcitized from their peripheral and central parts.

This type can be classified according to the rock type classification of natural aggregate according to BS812: Part 1 (1975, Trade group classification, Table 1) as limestone group. From the engineering point of view, the lower and upper yellow dolostone horizons are hard enough and can be used in concrete industry, while the limestone horizon can be used in road pavements. The geochemical analyses of these carbonate rocks revealed the presence of calcareous argillaceous siltstone/mudstone 


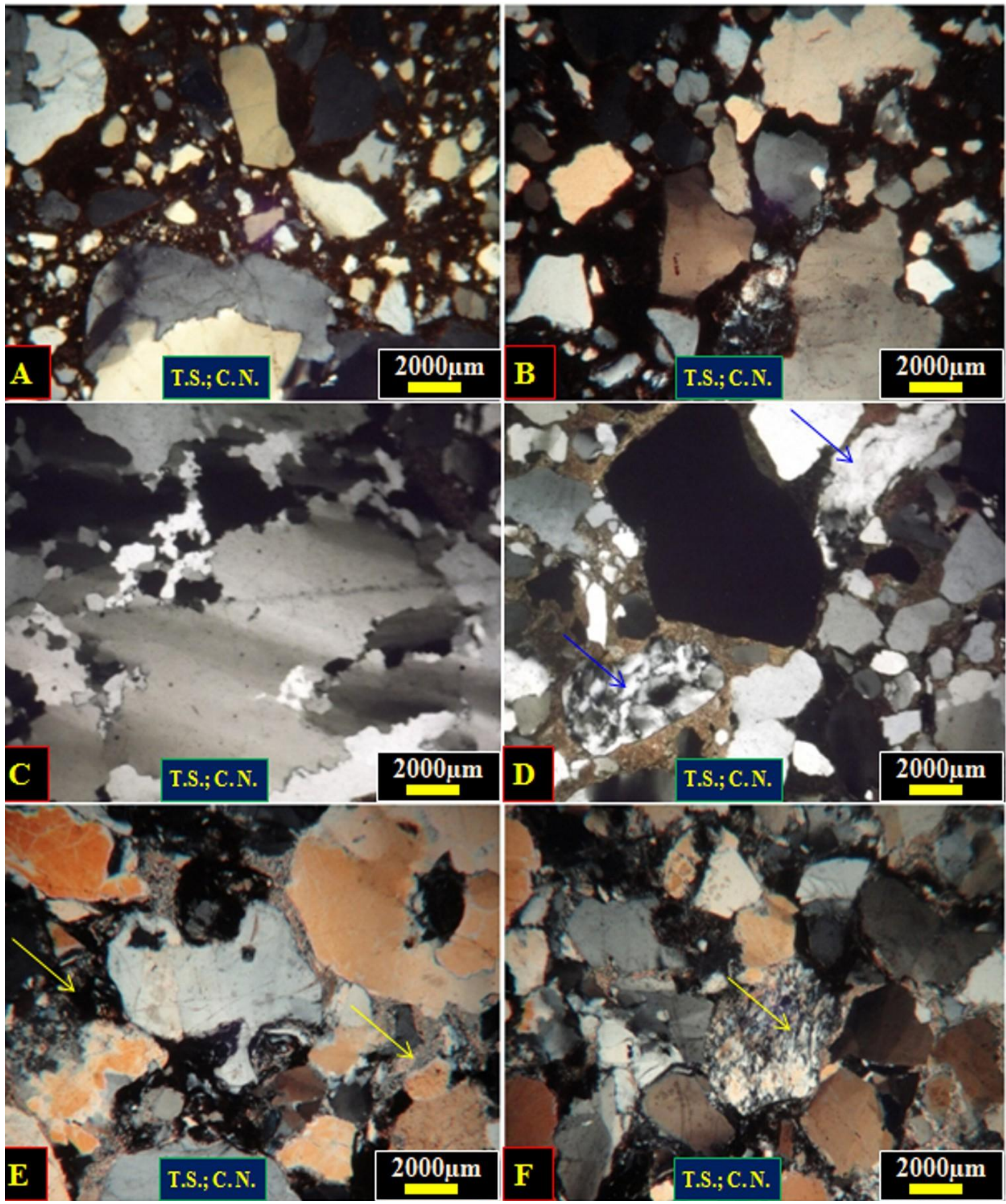

Figure 5. (A, B): Quartz grains (grey/white) embedded in slightly crystallized to amorphous isotropic kaolinitic/ tuffaceous clay matrix (black); (C, D): Polycrystalline quartz grains (white) of sutured contact and they are either embedded within amorphous kaolinitic clays matrix or cemented by microcrystalline quartz (arrows); (E, F): The quartz grains become cemented by gypsum and anhydrites lathlike aggregates (arrows). 

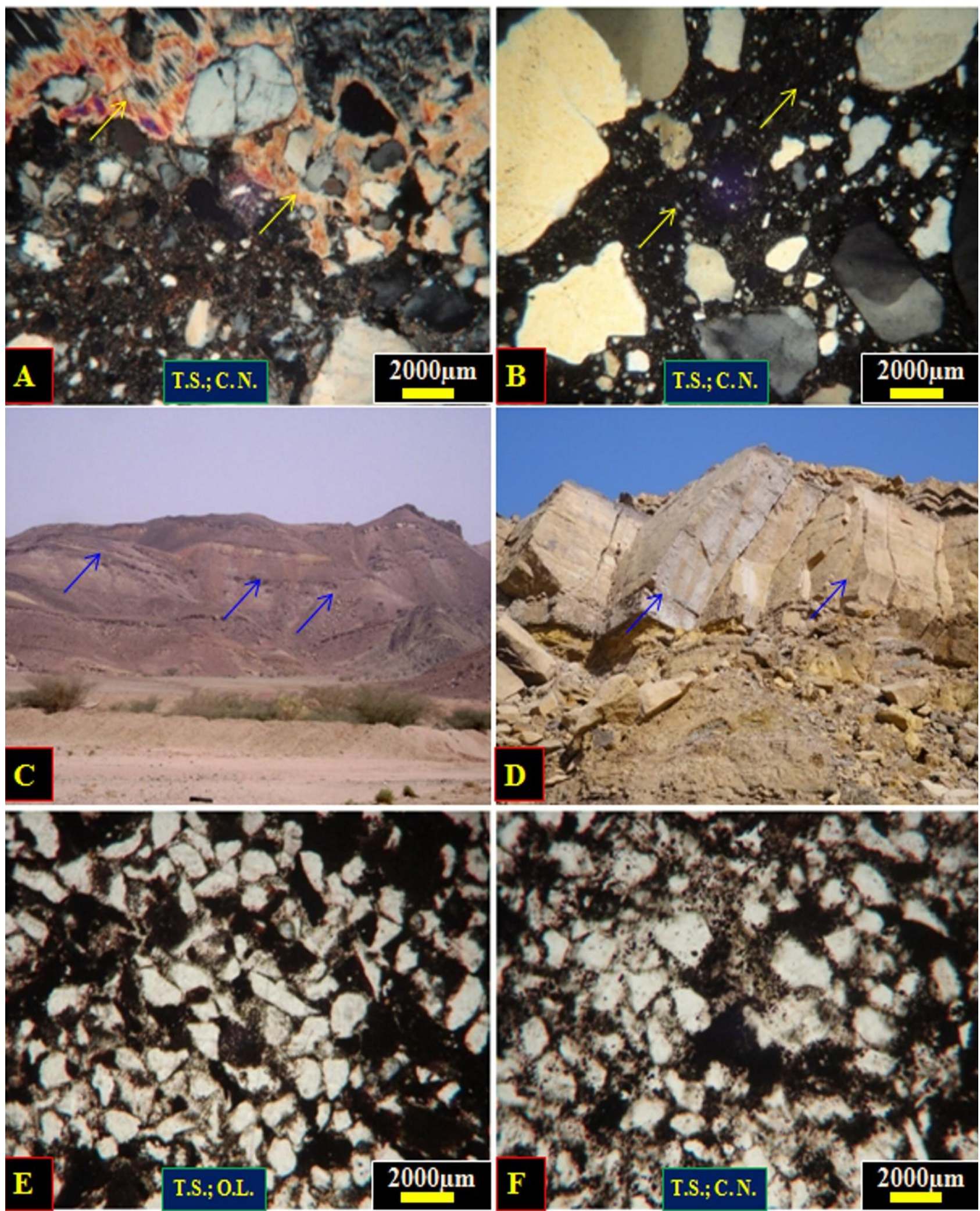

Figure 6. (A): Quartz grains corroded and embayed by the enclosing gypsum cement (arrows); (B): Quartz grains embedded within black (isotropic) material mostly amorphous kaolinitic clay matrix or tuffaceous glassy material (arrows); (C, D): The thick cliff-forming horizon of brown ferruginous sandstone (No. 3) within the middle shallow marine ironstone phosphatic carbonates member (arrows); (E, F): The ferruginous sandstone is composed from fine-to medium-grained, angular to subrounded quartz grains (white) cemented by black hematite cement. 
intercalated with the dolomitic carbonate beds (analysis no. 3, Table 3). These clastic intercalations are of relatively low content of $\mathrm{CaO}, \mathrm{TiO}_{2}, \mathrm{MnO}, \mathrm{MgO}, \mathrm{K}_{2} \mathrm{O}$. They contain high $\mathrm{Fe}_{2} \mathrm{O}_{3}$ values (up to 7.64) and low $\mathrm{CaO}$ (up to 7.27) when compared with the intercalated carbonate beds (Table 3, analysis no. 3). The carbonate beds (analysis no. 4, Table 3 ) are of characteristic lower $\mathrm{CaO}$ content (48.60).

\section{(5) Kaolinitic sandstone-mudstone (No. 5)}

This horizon is present in the upper part of the ferruginous mudstone/sandstone horizon just overlying the white carbonates unit No. 4 (Column B, Figure 2, and Figure 8A). It consists of rhythmic interbeds of white kaolinitic mudstone and reddish brown ferruginous sandstone/siltstone (Figure 8A, B). These beds are of cyclic nature and show upward increasing in the thickness of the ferruginous sandstone beds and decreasing in the thickness of the white kaolinitic mudstone interbeds (Figure 8B). The microscopic description of the ferruginous sandstone beds revealed its composition from fine- to medium-grained; moderately to well sorted quartz grains (Figure $8 \mathrm{C}, \mathrm{D}$ ). The quartz grains are either cemented by silicified hematite cement (Figure 8C) or by silica overgrowth cement (Figure 8D).

This type can be classified according to the rock type classification of natural aggregate according to BS812: Part 1 (1975, Trade group classification, Table 1) as gritstone and quartzite Groups. From the engineering point of view, the ferruginous sandstone interbeds and sheet can be easily quarried as small blocks $(20 \times 20 \mathrm{~cm})$ for building purposes. It is actually quarried for these purposes by the peoples of Haddat Ash Sham area. The white kaolinitic mudstone horizons intercalations are relatively thin and cannot be easily quarried for ceramic industry.

\section{(6) Ferruginous / silicified sandstone horizon (No. 6)}

This cliff-forming ferruginous sandstone horizon is present just above the previously described kaolinitic sandstone-mudstone (No. 5). It forms cliff-forming unit of bedded ferruginous sandstone (PI. 6E). Microscopic description of this sandstone revealed its composition from moderately to well sort quartz grains cemented by silica overgrowths (Figure 8F). Some poorly sorted domains also cemented by silica overgrowths are observed (Figure 9A). Ferruginous domains are observed in the upper part of this sandstone. It consists of quartz grains embedded in ferruginous kaolinitic clay matrix which contains some hematite patches (Figure 9B).

The geochemical analyses of this ferruginous sandstone bed (Table 4), revealed the presence of ferruginous siltstone beds (analyses no. 5, 6; Table 4) alternating with silicified sandstone beds (analysis No. 7 , Table 4). The siltstone beds (Table 4, analyses No. 5, 6) are of relatively higher $\mathrm{Al}_{2} \mathrm{O}_{3}, \mathrm{Fe}_{2} \mathrm{O}_{3}, \mathrm{TiO}_{2}$ and $\mathrm{K}_{2} \mathrm{O}$ and lower in $\mathrm{SiO}_{2}$ when compared with the siliceous sandstone beds (Table 4, analysis No. 7). The $\mathrm{SiO}_{2}$ content of the siliceous sandstone beds is due to the siliceous cement between the quartz grains (Figure 8F; Figure 9A, B). The high silica content of this sandstone types give it many physical properties (that is, hardness, durability and stability) suitable for many building and ornamental purposes. From the engineering point of view, this ferruginous sandstone unit can be used for decoration and facing, by selecting less fractured areas and taking large blocks $(2 \times 2 \mathrm{~m})$ which further subdivided into thinner sheets suitable for facing and decoration. This type can be classified according to the rock type classification of natural aggregate according to BS812: Part 1 (1975, Trade group classification, Table 1) as gritstone and quartzite Groups.

\section{(7) Ferruginous mudstones/sandstones (No. 7)}

This unit attains up to $30 \mathrm{~m}$ thick and it is composed mainly from chocolate brown ferruginous mudstone containing very thin ferruginous siltstone interbeds (Figure 9C, middle part of column B, Figure 2). The microscopic description of the thin ferruginous siltstone interbeds of this horizon, revealed its composition from silt-sized quartz grains embedded in ferruginous clay matrix (Figure 9D). Very thin Fe- clay flasers are present within this siltstone (Figure 9D). These flasers are composed from ferruginous clays stained by amorphous Fe-oxyhydroxides with less frequent silt-sized quartz grains (Figure 9E). Some highly silicified patches cemented by silica cement are also observed (Figure 9F). This type can be classified according to the rock type classification of natural aggregate according to BS 812: Part 1 (1975, Trade group classification, Table 1) as Gritstone group.

From the engineering point of view, this thick clay horizon is very suitable for bricks and cement industry. It is very easy to extract by open cast mining processes. The geochemical analyses of the ferruginous sandstone beds intercalated with the clay beds of this unit (Table 5 , No. 8, 9) revealed the $\mathrm{SiO}_{2}$ content (up to $81.88 \%$ ) and the presence of ferruginous clayey matrix which is indicated by the presence of appreciable $\mathrm{Fe}_{2} \mathrm{O}_{3}(6.10$, 2.49) and $\mathrm{Al}_{2} \mathrm{O}_{3} \%(7.37,9.62)$.

\section{(8) Ferruginous conglomerates (No. 8)}

This unit attains up to $25 \mathrm{~m}$ thick (upper part of column B, Figure 2). It consists mainly of red quartz pebble conglomerates and cross-bedded pebbly sandstones. This conglomerate is similar to the previously described 

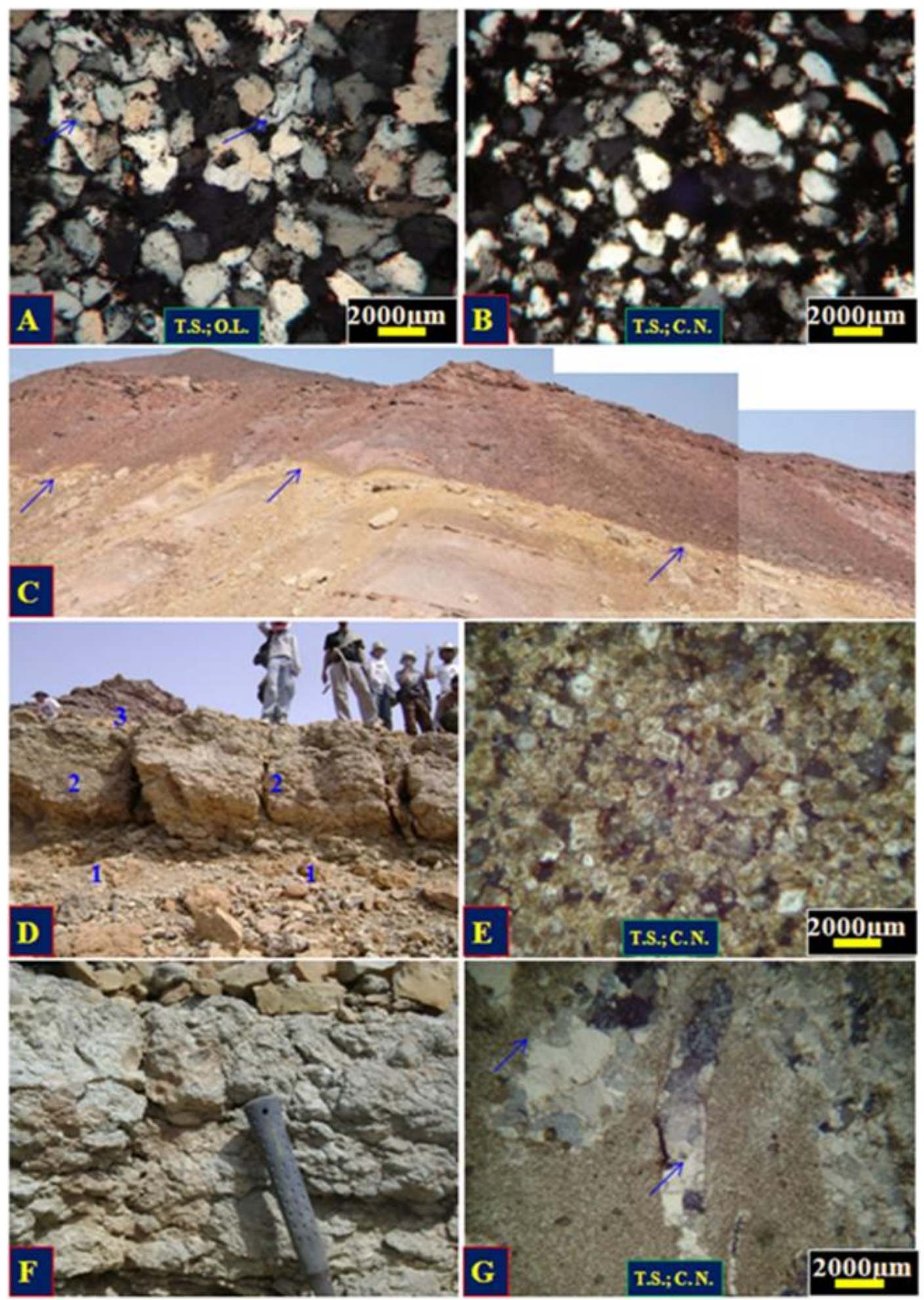

Figure 7. $(A, B)$ : The silicified sandstone variety is composed from moderately to well sorted mediumgrained quartz grains (white) cemented by silica overgrowths (arrows); (C): The laterally persistent yellow color carbonate horizon (arrows) within the brownish ferruginous mudstone- sandstone succession; (D): The three horizons of carbonate unit: 1) lower yellow dolomitic mudstone unit, 2) middle thick grayish white fossiliferous limestone unit and 3) an upper thin yellow dolostone unit; (E): Fine crystalline dolomite of the lower yellow dolomite unit; (F): The middle limestone bed which contains large gastropod shells; (G): Bioclastic pack/ and grainstone ground mass of the middle limestone bed contains calcitized shell fragments (arrows). 
Table 2. Major oxide analyses of the ferruginous sandstone type 3.

\begin{tabular}{ccccccccccc}
\hline Oxides \%/No & $\mathrm{CaO}$ & $\mathrm{Al}_{2} \mathrm{O}_{3}$ & $\mathrm{Fe}_{2} \mathrm{O}_{3}$ & $\mathrm{SiO}_{2}$ & $\mathrm{P}_{2} \mathrm{O}_{5}$ & $\mathrm{TIO}_{2}$ & $\mathrm{MnO}$ & $\mathbf{M g O}$ & $\mathrm{K}_{2} \mathrm{O}$ & $\mathrm{LOI}$ \\
\hline 1 & 0.11 & 9.00 & 10.49 & 72.21 & 0.13 & 1.38 & 0.07 & 0.47 & 0.55 & 5.06 \\
2 & 0.12 & 9.45 & 10.93 & 68.53 & 0.15 & 1.32 & 0.03 & 0.79 & 0.73 & 6.85 \\
\hline
\end{tabular}

Table 3. Major oxide analyses of the carbonates type 4.

\begin{tabular}{ccccccccccc}
\hline Oxides \%/ No & $\mathrm{CaO}$ & $\mathrm{Al}_{2} \mathrm{O}_{3}$ & $\mathrm{Fe}_{2} \mathrm{O}_{3}$ & $\mathrm{SiO}_{2}$ & $\mathrm{P}_{2} \mathrm{O}_{5}$ & $\mathrm{TIO}_{2}$ & $\mathrm{MnO}$ & $\mathrm{MgO}$ & $\mathrm{K}_{2} \mathrm{O}$ & $\mathrm{LOI}$ \\
\hline 3 & 7.27 & 4.51 & 7.64 & 63.29 & 1.23 & 0.52 & 0.05 & 0.41 & 0.11 & 8.75 \\
4 & 48.60 & 1.50 & 1.47 & 5.50 & 0.20 & 0.08 & 0.01 & 1.42 & 0.12 & 40.61 \\
\hline
\end{tabular}

Table 4. Major oxide analyses of the ferruginous/silicified sandstones type 6 .

\begin{tabular}{ccccccccccc}
\hline Oxides $\% / \mathrm{No}$ & $\mathrm{C}_{\mathrm{a}} \mathrm{O}$ & $\mathrm{Al}_{2} \mathrm{O}_{3}$ & $\mathrm{Fe}_{2} \mathrm{O}_{3}$ & $\mathrm{SiO}_{2}$ & $\mathrm{P}_{2} \mathrm{O}_{5}$ & $\mathrm{TIO}_{2}$ & $\mathrm{MnO}$ & $\mathrm{MgO}$ & $\mathrm{K}_{2} \mathrm{O}$ & $\mathrm{LOI}$ \\
\hline 5 & 0.9 & 3.52 & 1.51 & 92.21 & 0.03 & 1.03 & 0.01 & $<0.01$ & 0.36 & 1.38 \\
6 & 0.33 & 2.58 & 2.10 & 91.77 & 0.04 & 1.11 & 0.02 & 0.12 & 0.36 & 1.52 \\
7 & 0.10 & 1.45 & 0.63 & 95.99 & 0.02 & 0.07 & 0.01 & 0.04 & $<0.01$ & 1.04 \\
\hline
\end{tabular}

Table 5. Major oxide analyses of Ferruginous Mudstones/sandstones type 7.

\begin{tabular}{ccccccccccc}
\hline Oxides \%/ No & $\mathrm{C}_{\mathrm{a}} \mathrm{O}$ & $\mathrm{Al}_{2} \mathrm{O}_{3}$ & $\mathrm{Fe}_{2} \mathrm{O}_{3}$ & $\mathrm{SiO}_{2}$ & $\mathrm{P}_{2} \mathrm{O}_{5}$ & $\mathrm{TIO}_{2}$ & $\mathrm{MnO}$ & $\mathrm{MgO}$ & $\mathrm{K}_{2} \mathrm{O}$ & $\mathrm{LOI}$ \\
\hline 8 & 0.19 & 7.37 & 6.10 & 81.88 & 0.02 & 0.50 & 0.02 & 0.08 & 0.03 & 3.71 \\
9 & 0.77 & 9.62 & 2.49 & 80.13 & 0.02 & 0.62 & 0.01 & 0.11 & 0.06 & 5.44 \\
\hline
\end{tabular}

conglomerates of No. 1. It is poorly sorted and consists mainly of red and white quartz pebbles embedded in finer matrix of kaolinitic and ferruginous sandstone. This type can be classified according to the rock type classification of natural aggregate according to BS812: Part 1 (1975, Trade group classification, Table 1) as Gritstone group. From the engineering point of view, this conglomerate type is suitable for concrete industry.

\section{Conclusion}

The present study is based mainly on detailed field, mega and microscopic investigations of some possible building, ornamental and industrial minerals and rocks in the sedimentary Tertiary succession of Haddat Ash Sham area, western Arabian Shield, Saudi Arabia. The study revealed the presence of different levels of these materials within the sedimentary succession (numbers from 1 to 8 ). Most of the building, industrial and ornamental stones can be easily extracted where the study area is crossed by main N-S or NE-SW asphaltic road. They include conglomerates, sandstones, siltstones, clays and carbonates. The conglomerates of number 1 and 9 are very suitable for concrete industry while the ferruginous cliff-forming sandstones of numbers 3,6 are very suitable for blocking, decoration and facing of buildings. These two horizons are now quarried as small blocks for private buildings in Haddat Ash Sham area.

The carbonate rocks in Haddat Ash Sham are present in one horizon (up to $6 \mathrm{~m}$ only) and are represented by limestones and dolomites which may be used for cement industry and concrete. The clay deposits are of huge reserves and must be evaluated from the economic point of view for cement and ceramic industries. The geochemical analyses of some horizons of these building, ornamental and industrial materials, revealed its suitability from the engineering (building and ornamental stones) and from the chemical compositions (industrial clays and carbonates) points of views. 

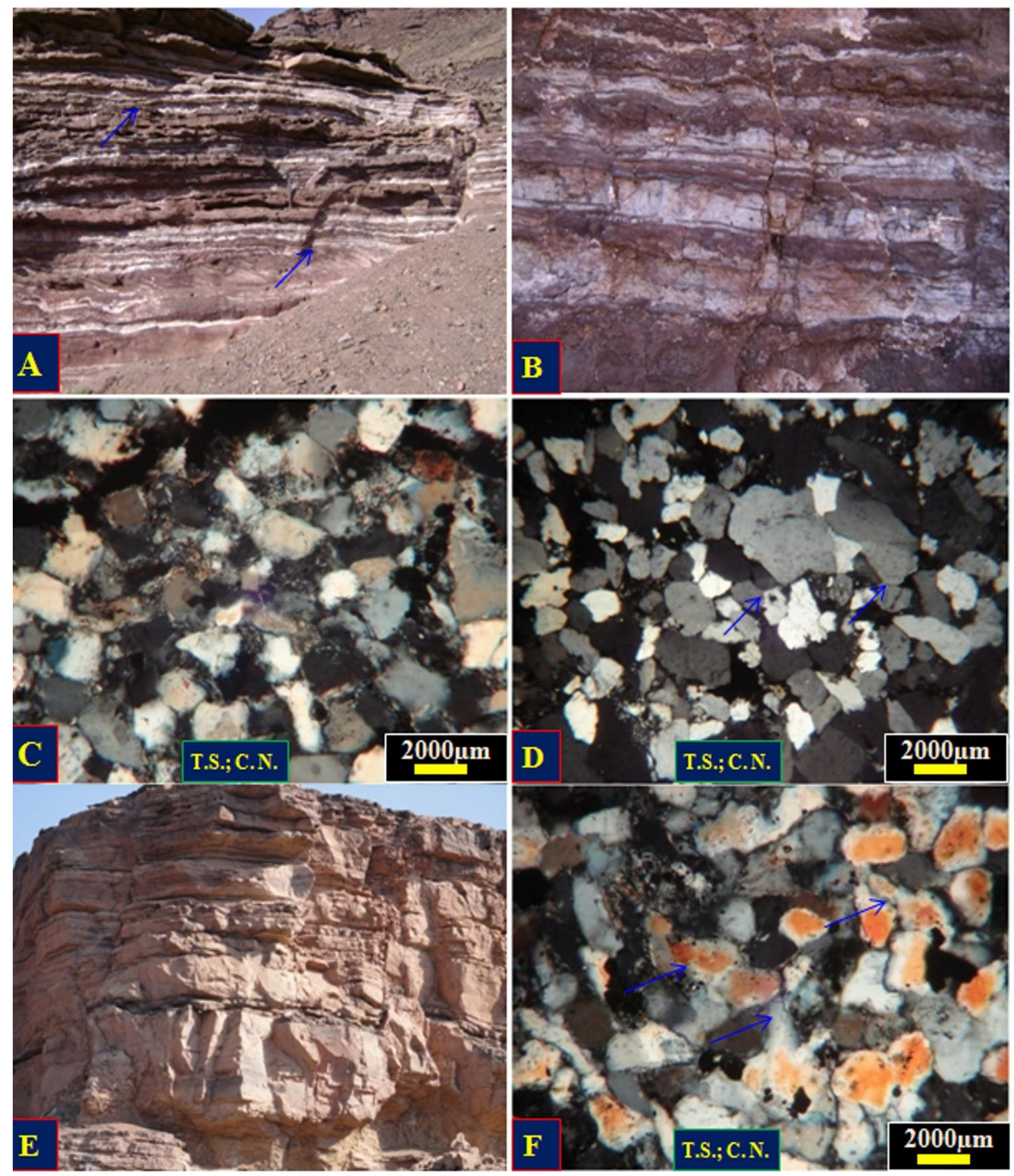

Figure 8. (A, B): The rhythmic interbeds of white kaolinitic mudstone and reddish brown ferruginous sandstone / siltsone of the kaolinitic sandstone-mudstone (No. 5); (C, D): Fine- to medium-grained; moderately to well sorted quartz grains cemented by silicified hematite cement (black) or by silica overgrowth cement (arrows); (E): Cliff-forming unit of bedded ferruginous sandstone (No. 6); (F): The sandstone of Figure E, is composed from moderately to well sorted quartz grains cemented by silica overgrowths (arrows). 

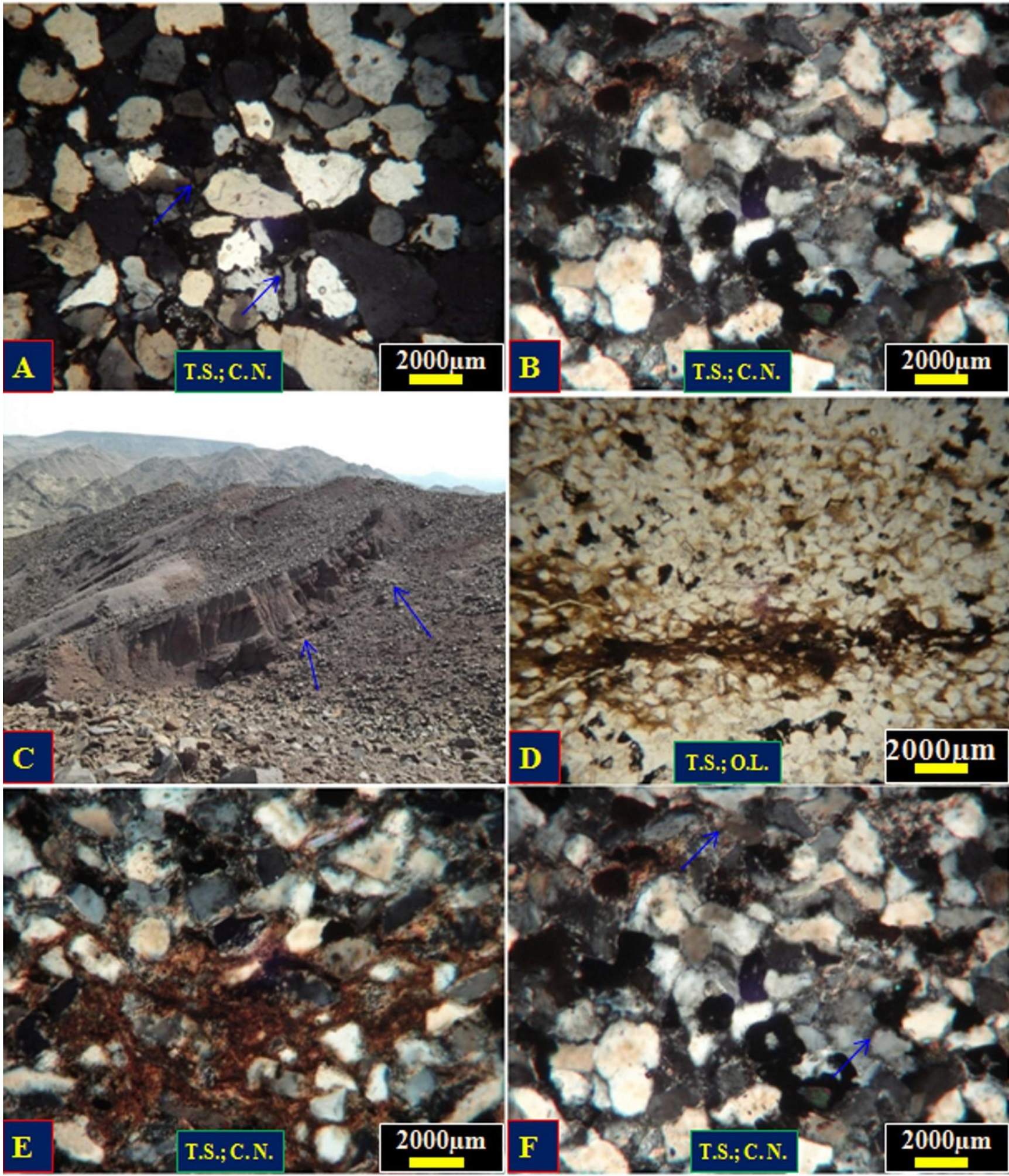

Figure 9. A: Silica overgrowths (arrows) on the quartz grains (white). Ferruginous domains are observed in the upper part of this sandstone; B: Quartz grains embedded in ferruginous kaolinitic clay matrix contains some black hematite patches; C: Chocolate brown ferruginous mudstone (arrows) which is composed from ferruginous mudstone containing very thin ferruginous siltstone interbeds; D: The ferruginous siltstone interbeds of Figure $\mathrm{C}$, is composed from silt-sized quartz grains (white) embedded in ferruginous clay matrix (reddish black); E: The ferruginous flasers of Figure D, are composed from quartz grains embedded in ferruginous clays stained by amorphous Fe-oxyhydroxides (red); F: Silicified patches composed from quartz grains (white) cemented by silica cement(arrows). 


\section{REFERENCES}

Al-Shanti AM (1966). Oolitic iron ore in Wadi Fatima, between Jeddah and Mecca. Directorate General Min. Resour. Bull. 2:51.

Brown GF, Jackson RO, Bogue RG, MacLean WH (1963). Geology of the Southern Hijaz quadrangle, Kingdom of Saudi Arabia: Saudi Arabian Directorate General of Mineral Resources, Miscellaneous Geologic investigations MAP I - 210 A, 1:500,000 scale.

BS812: Part 1 (1975). Trade group classification of natural aggregates.

Johnson PR (2006). Explanatory notes to the map of proterozoic geology of western saudi Arabia, technical report SGS-Tr-2006-4.

Karpoff R (1957a). Esuuisse geologique de I Arabie Seoudite: bull. Soc.Geol. Fr. 6. ser.; 7:653-667.

Karpoff R (1957b). Sur I existence du Maestrichtiane au Nord de D Jeddah (Arabia Seoudite: Compt. Rend. Séance Acd. Sci. 245:13221324.

Moore TA, Al-Rehaili MH (1989). Geologic map of the Makkah Quadrangle, sheet 21D, Kingdom of Saudi Arabia. Saudi Arabian Directorate General of Mineral Resources, Geoscience Map GM107C, Scale 1:250,000, with text, Jeddah, Saudi Arabia. P. 62.
Spincer CH, Vincent PL (1984). Bentonite resource potential and geology of the Cenozoic sediments, Jeddah region: Saudi Arabian Deputy Ministry for Mineral Resources, Open-File Report BRGM-OF-02-34. P. 34.

Taj RJ (2011). Stratigraphic setting, facies types and depositional environments of Haddat Ash Sham ironstones, Western Arabian Shield, Saudi Arabia. Asian Transactions on Basic \& Applied Sciences (ATBAS ISSN: 2221-4293), 01:02. 